\title{
Should 4th Grade ELL Students Read Aloud or Silently? Empirical Implications from Subsets of Data Taken from Two Large Databases
}

\author{
Siping Liu \\ College of Foreign Languages and Literature, Wuhan University, China
}

\begin{abstract}
This study addresses the predictive effects of reading aloud and silent reading on the fourth grade level English language learner (ELL) children. Reading aloud was recommended as a teaching practice to develop phonological awareness, an essential skill for meaningful reading comprehension. However, according to the theories of second language acquisition, ELL children at intermediate grade may transfer their first language reading skills in English reading and they may have outgrown the intensive training of phonological awareness by the fourth grade. Therefore, I contend that silent reading is more effective for intermediate grade level ELL children to develop English reading comprehension. The quantitative analyses of data collected from two large datasets, PIRLS and NAEP, indicate that reading aloud predicts negative effect while silent reading predicts positive predictive effect on ELL children' reading performance at fourth grade. My study suggests that at intermediate or higher grades ELL children should be encouraged to read silently.
\end{abstract}

Index Terms—reading aloud, reading silently, ELL children, large database

\section{INTRODUCTION}

Reading aloud as a practice to develop oral fluency is recommended in the U.S. educational policy to help ELL students develop phonological awareness, which is identified as one of the major obstacles for ELL children in English reading development (Gersten et al, 2007). Because ELL students do not develop English phonological awareness naturally, practicing reading aloud is assumed to be necessary for beginning readers to establish sound-symbol relationship that will lay the foundation for cognitive processing in reading comprehension (Griffin, 1992).

However, the current US policy recommendations to improve reading instruction for ELL students were developed based on research on reading development of students who speak English as their first language (L1). In the field of second language acquisition, ELL students' reading development in English is often assumed different from the developmental pattern of English monolingual or native English speaking children (Koda, 2005). English monolingual children follow a bottom-up pattern. They develop their reading proficiency by first identifying letters, recognizing phonemes, learning vocabulary, and then they process meaningful reading comprehension using the skills that they have developed initially (Paris \& Hamilton, 2009; Chall, 1996). Such pattern is seen as not a true reflection of English as a second language (L2) reading development (Johnson \& Afflerbach, 1985). L2 readers, especially those who have already been exposed to their native language learning and teaching, may have developed certain level of reading proficiency in their first language. With some first language reading experience, even if ELL readers do not have a strong phonological awareness in English, they can transfer the skills developed in their first language as support (Adams 1994; Hamada \& Koda, 2010).

Because of different reading developmental patterns, reading instruction effective for L1 reading is not necessarily equally effective for L2 reading development. Consequently, it is reasonable to question whether ELL students need to repeat the natural reading developmental pattern like English monolingual students regardless of their age and in particular, whether reading aloud that aligns with English monolingual children's reading development can be equally effective for the ELL students who have developed some first language literacy experience before they learn English (Jacobs \& Farrell, 2001).

In contrast to reading aloud, silent reading allows ELL children, especially those who have developed some reading proficiency in their native language, to develop a sense of control and ownership by making use of their existing reading skills and background knowledge developed in their first language (Meyer, Wardrop, Linn \& Hastings, 1993) and to focus their attention to content words for reading comprehension rather than every word for correct pronunciation in reading aloud practice (Gabrielatos, 2002).

Because reading aloud and silent reading have different functions when ELL students process reading comprehension, it is necessary to examine whether it is reading aloud or silent reading that is more effective for ELL students, especially those at intermediate grades who have developed some reading and cultural experiences in their first language environments. In particular, the fourth grade level is the turning point for ELL students to change from learning to read to reading to learn (Chall, 1996). Thus, to examine the different predictive effects of the two reading activities on this age group of ELL students, I raise the following two research questions: 
1. Will reading aloud activity have predictive effect on the reading proficiency of fourth grade ELL students? If yes, how big is the predictive effect on ELL students' reading proficiency?

2. Will silent reading have predictive effect on the reading proficiency of fourth grade ELL students? If yes, how big is the predictive effect on ELL students' reading proficiency?

Answers to the above questions will first help offer direct empirical bases that may support, enrich, and challenge the policy regarding ELL student reading development (Gersten et al, 2007). They will also help verify indirectly the theoretical assumptions about L1 and L2 reading development and their differences by providing necessary and more reliable empirical evidences (Koda, 2007). These assumptions have been used as the important conceptual bases for the reading instruction policy for English monolingual and ELL students alike (Cummins, 1979).

\section{THEORETICAL FRAMEWORK}

My study is directly motivated by the following theoretical assumptions about reading development emerging from the literature of L1 reading development and the challenges from the theoretical perspectives of L2 reading development. The two research questions nested in these theoretical contentions are designed to examine directly the two reading activities based on these theoretical assumptions and also to examine indirectly each of assumptions themselves.

Reading aloud activity is seen to be critical for developing children's reading comprehension because of its potential in developing their phonological awareness. Phonological awareness is defined as "the ability to perceive and manipulate the sounds of spoken words" and it is seen to be fundamental for a child to process reading comprehension (Castles \& Coltheart, 2004, p. 73). In particular, to learn to read, children need to understand how words are segmented into sequences of phonemes and the phonemic constituents by analyzing the internal structure of words (Liberman, Shankweiler \& Liberman, 1989; Ball \& Blachman, 1991).

In the literature of $\mathrm{L} 1$ reading research, the positive relationship between phonological awareness and reading is richly documented (Adams, 1990; Bryant, MacLean and Bradley, 1990; Brady \& Shankweiler, 1991; Goswami \& Bryant, 1990; Caravolas \& Bruck, 1993; Durgunoglu \& Oney, 1999). These studies confirmed that the level of phonological awareness could predict how successfully one could read in his or her first language. With this understanding of the role of phonological awareness in reading development, researchers (e.g., Nation \& Cocksey, 2009; Griffin, 1992) suggested a possible link between readers' phonological knowledge and their practice of reading words aloud. As Griffin (1992) explained, when learning to read, children cannot predict the pronunciation of words in a text, and therefore to practice reading aloud is a good way to increase their "auditory experiences with the target language by exposing them to words that they would not ordinarily hear in spoken form" (p. 784).

Similar to English monolingual children, phonological awareness is also assumed important in developing L2 reading. Koda (2007) and Nassaji and Geva (1999) contended that the development of L2 reading proficiency followed the identical trend of L1 reading. The reason for ELL children who could not develop efficient reading comprehension in English was that they did not have reliable English phonological stock in the working memory that stored phonological information (Walter, 2008). With sufficient phonological stock, ELL children are capable of converting visually presented words phonologically, and this capability is one of the essential skills for L2 reading comprehension (Hamada $\&$ Koda, 2010). The above assumption of the role of phonological awareness in L2 reading development leads to the suggestion that reading aloud can be equally necessary to help ELL students learn to read effectively (Koda, 2007; Nagy \& Anderson, 1999).

Such assumption can be important for younger ELL children who have no or little reading experience in either English or their first language. However, it can be problematic for ELL children at intermediate or higher grade level when they can transfer the relevant phonological awareness of their first languages to English reading, especially when both languages are in alphabetic writing system (Bruck, Genesee \& Caravolas, 1997; Caravolas \& Brack, 1993; Jiménez González \& García, 1995). Such transfer is built on ELL children's ability to rehearse the stored phonological information subvocally in first language "as a means of silently maintaining the contents of the phonological store" useful for L2 reading development (Baddeley, Gathercole \& Papagno, 1998, p. 167). Besides, the natural oral English environment also helps develop ELL children's English phonological knowledge subconsciously (Hamada \& Koda, 2010). In this sense, the assumption that ELL students have little phonological awareness for their L2 reading development can be inaccurate and reading aloud activity in English only based on such an assumption can be questionable.

Another challenge for the assumption that ELL students need to read aloud first to develop reading comprehension is the misunderstanding that ELL students have little L2 reading experience in supporting their reading development and thus, they simply need to learn to read and cannot read to learn or both (Chall, 1996). This assumption again can be problematic in that although ELL students have little L2 reading experience, many, especially older ELL students, may have acquired some or even substantial reading experience and skills in their first language, which is assumed useful for them to process reading materials in L2 reading (Adams 1994). This means that like L1 children, older ELL children may also use top-down approach to facilitate their reading comprehension as their relevant first language reading skills are more likely to help them read to learn than their weak oral reading accuracy in English (Goodman, 1976). Fuchs, Fuchs, Hosp, and Jenkins (2001) posited that "the typical developmental trajectory of oral reading fluency involves the 
greatest growth in the primary grades, with a negatively accelerating curve through the intermediate grades and perhaps into junior high school" (p. 242). Following this assumption, it is reasonable to question whether it is reading aloud or silent reading that is more effective in helping ELL children, especially older ones, in developing their L2 reading comprehension (Chall, 1996).

\section{EMPIRICAL LITERATURE REVIEW}

\section{A. Reading Aloud}

My review of three available empirical studies cannot sustain the relationship between reading aloud and reading comprehension for intermediate grade level ELL students.

Two empirical studies I reviewed focused on how reading aloud helped young children develop phonological awareness. The first study was based on the data collected from 659 kindergarten children who were divided into group of English only, group of bilingual, and group of ELL students. Chiappe, Siegel and Gottardo (2002), the authors of the first study, found that constant reading aloud was a strong predictor for the development of phonological awareness for all groups of children regardless of their different first language literacy backgrounds. In the second study, Lafrance and Gottardo (2005) examined longitudinally how 40 English as second language children from kindergarten to first grade classes developed phonological awareness through reading aloud. Based on multiple regression analysis of the data collected at interval from kindergarten to first grade, the authors found that reading aloud was a strong predicator of the development of phonological awareness. The only study (Amer, 1997) I found addressing higher grade level elementary school students focused on students who learned English as a foreign language (EFL). The study found that 75 sixth grade Egyptian EFL students' performance in phonological awareness in the experimental group who listened to their teacher reading aloud every day in a 50-minute class was significantly higher than those in the control group who read on their own.

In summary, my review did not find sufficient empirical evidence to support the positive predictive effect of reading aloud on the development of ELL students' reading proficiency, especially intermediate grade level students who may have developed some first language reading skills and who have the experience of being exposed to oral English in natural English environment. Thus, an empirical study involving well represented ELL population and using more standard measurement of the relationship between reading aloud teaching activity and student reading comprehension is still necessary.

\section{B. Silent Reading}

The search for empirical studies on the relationship between silent reading and ELL student reading development came with no empirical studies addressing ELL students at intermediate grade level. Therefore, I included in the review the studies addressing older and adult ELL learners, who are assumed to share similarity with intermediate grade ELL students in terms of first language literacy experience.

The review of empirical research on the relationship between silent reading and L2 reading development for older ELL students supported the theoretical assumption that silent reading helped improve ELL students' reading comprehension (Wallace, 1992). Based on the answers to a survey question collected from 43 international undergraduates studying in the United States, Constantino, Lee, Cho, and Krashen (1997) found that the amount of silent reading significantly differentiated the participants' TOEFL scores. Those who read more than 50 English books scored 613 and those who did not read English books scored 543. Silent reading was also found to be positively related to L2 vocabulary development. Kweon and Kim (2008) asked 12 second language undergraduates read three unsimplified chapter books over five weeks. Students' performance between pretest and posttest indicated $40 \%$ pure word acquisition increase, which supported the argument that silent reading had a powerful influence on incidental vocabulary acquisition. Finally, silent reading was found to be more effective than teacher-taught reading. To compare the effects of extensive silent reading and teacher-taught intensive reading on reading comprehension of seventeen 13to 18-years-old ELL students, Al-Homoud and Schmitt (2009) divided the participants into one group receiving extensive reading treatment and the other receiving intensive reading treatment. After four 50-minute treatment each week for 10 weeks, the result showed that the extensive group outperformed the intensive group in reading comprehension. A subsequent questionnaire showed that the extensive group held a more positive attitude towards their learning experience than the intensive one.

The above reviewed studies showed a positive relationship between silent reading and English vocabulary growth and reading comprehension, which may indicate that older ELL students might be able to take the advantage of their first language experience and knowledge in their L2 reading development. However, because none of the studies addressed elementary school ELL students at intermediate grade level, it is still necessary to verify the assumption that silent reading helps ELL students at this level develop reading comprehension.

\section{METHODS}

\section{A. Data Source}

To address the limitations in the literature reviewed for the research on the reading development of intermediate 
grade level ELL students, I draw data from two large scale databases, i.e., the Progress in International Reading Literacy Study (PIRLS), an international database and the National Assessment of Educational Progress (NAEP), a US national database. The two databases are selected based on several considerations about their similarities and differences as shown on Table 1.

TABLE 1

SIMILARITIES AND DIFFERENCES BETWEEN PIRLS AND NAEP

\begin{tabular}{|l|l|l|}
\hline \multicolumn{1}{|c|}{ Items } & \multicolumn{1}{|c|}{ PIRLS } & NAEP \\
\hline Sample students' grade level & Fourth & Fourth \\
\hline Sampling method & Probability proportional to size & Probability proportional to size \\
\hline Identification of ELL students & Students' response to survey questions & Principal's response survey questions \\
\hline Independent variables & Students' response to survey questions & Students' response to survey questions \\
\hline $\begin{array}{l}\text { Definition of reading } \\
\text { comprehension }\end{array}$ & $\begin{array}{l}\text { Literary experience and gaining } \\
\text { information }\end{array}$ & Literary experience and gaining information \\
\hline Score range & $0-1000$ & $0-500$ \\
\hline Subjects to measure & Reading & Multiple \\
\hline Availability of data & One administration & Multiple administrations \\
\hline Analysis & Regression & Correlation \\
\hline
\end{tabular}

In terms of similarity, PIRLS and NAEP are large scale assessment studies providing large and well represented ELL population at fourth grade level in the United States (Binkley \& Kelly, 2003). The probability-proportional-to-size sampling used in the two databases guarantee the chances of selecting a member from a smaller subgroup is more than from a large subgroup (Rutkowski, Gonzalez, Joncas \& von Davier, 2010). With this sampling strategy, PIRLS secured an average sample size of 5,190 US fourth grade students in its most recent available data, i.e., the 2006 PIRLS (Baer, Baldi, Ayotte \& Green, 2007). NAEP randomly selected its sampling students, and each state in US had approximately 2,500 to 3,000 students at fourth grade for NAEP reading test (NCES, 2010).

PIRLS and NAEP identified ELL student status with survey questions attached to their reading tests. The participant students on PIRLS responded to the question whether they speak a different language other than English before they start school and whether they have developed some literacy experience in their home language. Based on their answers, I identified 351 ELL students in 2006 PIRLS and used them as the representative sample in my study (Joncas, 2007). Based on the principals' response to the survey question whether the selected students on NAEP were ELL students and whether they could read in their home language, I identified about 5\% of them as appropriate sample for my study (Nation's Report Card, 2009). I also construct the independent variables based on PIRLS and NAEP survey questions asking the participant students how often their teachers asked them to read aloud and read silently.

I construct the dependent variable based on the participant ELL students' reading performance, which is built on the shared definition of PIRLS and NEAP that reading is a constructive and interactive process involving interaction between readers and texts and reading is involved with two purposes, reading for a literary experience and reading for information (Rutkowski, Gonzalez, Joncas \& von Davier, 2010; von Davier, Sinharay, Oranje \& Beaton, 2006). The PIRLS students' average score was 500 and the NAEP students' average score was 220 (Ogle et al., 2003; NCES, 2010).

The differences between PIRLS and NAEP are also useful in helping examine the research questions. Targeting exclusively at fourth grade students, PIRLS provides a clearly defined population at this level (Campbell, Kelly, Mullis, Martin, \& Sainsbury, 2001, p. 3). NAEP is suitable for long-term trend analysis because its data on ELL student reading aloud and silent reading are available for three to four NAEP administrations in a row (NAGB, 2003).

Another difference is the availability of data for analysis, which is one of the important reasons for me to include both PIRLS and NAEP. PIRLS data are open to public for various levels of analyses including regression but the sample size of ELL students is not big compared with NAEP (Mullis, Kennedy, Martin \& Sainsbury, 2006). As a US national assessment, NAEP takes into account of students' ethnical and racial backgrounds based on US students' composition (NABG, 2008). Thus it includes a large ELL student sample size. But NAEP restricts personal access to its data within basic analysis. Due to this restriction, I can only analyze correlation between the selected variables and student reading performance. The use of both databases provides wider representative samples and compensates for the constraints that each of the databases may incur.

\section{B. Data Analysis}

The simple linear regression I use to analyze PIRLS data aims to examine the predictive effect of each of the independent variables on the dependent variable. The following regression equation is used to address the research questions. The null hypotheses is $Y^{\prime}=\alpha+\beta X_{i}$, where $Y^{\prime}$ is the predicted value of ELL students' reading performance on PIRLS, $\alpha$ is the $Y$ intercept, $\beta$ is the unstandardized coefficient for the predictor variable calculated from the regression analysis, and $X_{i}$ is the raw value for a predictor variable. The simple linear regression determines the statistical significance of each of the predictor variables of the reading activities on the dependent variable of ELL students' reading composite score in the equation. To analyze NAEP data, I examine the correlation between the two reading activities and fourth grade ELL students' overall reading performance.

\section{RESULTS}


My analysis led to two findings relevant to the predictive effect of reading aloud on the participant ELL students' reading comprehension performance. First, instead of helping improve ELL students' reading performance, reading aloud, no matter teachers read aloud in class or students read aloud at home, negatively influenced ELL students' reading performance.

As shown on Table 2 below based on the analysis of data from PIRLS, the coefficient output between teachers' reading aloud and ELL students' reading performance was significantly negative. The unstandardized regression coefficient for reading aloud, $b=-13.135, t_{(346)}=-3.314, p<.001$, indicated that when the participants listened to their teachers reading aloud one unit higher, their reading performance on PIRLS decreased by 13.135 points, e.g., from reading aloud once or twice a week to every day or almost every day.

TABLE 2.

READING-ALOUD AND ELL STUDENT READING ACHIEVEMENT IN PIRLS DATA $(N=347)$

\begin{tabular}{|c|c|c|c|c|c|}
\hline \multirow[t]{2}{*}{ Model } & \multicolumn{2}{|c|}{ Unstandardized Coefficents } & \multirow{2}{*}{$\begin{array}{l}\text { Standardized Coefficients } \\
\text { Beta }\end{array}$} & \multirow[t]{2}{*}{$t$} & \multirow[t]{2}{*}{ Sig. } \\
\hline & $B$ & Std. Error & & & \\
\hline (Constant) & 494.357 & 7.704 & - & 64.170 & .000 \\
\hline TCH READ ALOUD IN CLS & -13.135 & 3.963 & -.175 & -3.314 & $.001^{*}$ \\
\hline (Constant) & 489.3118 & 9.293 & - & 52.656 & .000 \\
\hline OUTSIDE SCH/READ ALOUD & -10.879 & 3.363 & -.172 & -3.235 & $.001 *$ \\
\hline
\end{tabular}

Still shown on Table 2, the relationship between the participants' reading aloud on their own and their reading performance is also significantly negative. The unstandardized regression coefficient for reading aloud, $b=-10.879$, $t_{(346)}=3.235, p<.001$, indicated when ELL students practiced reading aloud at home one unit higher, their predicated reading performance on PIRLS decreased by 10.879 points, e.g., from once or twice a week to every day or almost every day.

TABLE 3

\begin{tabular}{|c|c|c|c|c|}
\hline \multicolumn{5}{|c|}{ MEAN SCORE DIFFERENCES BETWEEN VARIABLES FOR READING ALOUD IN NEAP DATA } \\
\hline 2011 & $\begin{array}{l}\text { Never or hardly ever } \\
\text { (226) }\end{array}$ & $\begin{array}{l}\text { Once or twice a month } \\
(229)\end{array}$ & $\begin{array}{l}\text { Once or twice a week } \\
(224)\end{array}$ & $\begin{array}{l}\text { Almost every day } \\
\text { (219) }\end{array}$ \\
\hline Never or hardly ever (226) & & & & $>$ Diff $=7 * *$ \\
\hline Once or twice a month (229) & & & $>\operatorname{Diff}=5 * * *$ & $>$ Diff $=10 * * *$ \\
\hline Once or twice a week (224) & & & & $>$ Diff $=5 * * *$ \\
\hline \multicolumn{5}{|l|}{ Almost every day (219) } \\
\hline 2009 & $\begin{array}{l}\text { Never or hardly ever } \\
(224)\end{array}$ & $\begin{array}{l}\text { Once or twice a month } \\
(228)\end{array}$ & $\begin{array}{l}\text { Once or twice a week } \\
(223)\end{array}$ & $\begin{array}{l}\text { Almost every day } \\
\text { (219) }\end{array}$ \\
\hline Never or hardly ever (224) & & & & $>$ Diff $=5^{* *}$ \\
\hline Once or twice a month (228) & & & $>$ Diff $=4 * *$ & $>$ Diff $=8 * * *$ \\
\hline Once or twice a week (223) & & & & $>\operatorname{Diff}=4 * * *$ \\
\hline \multicolumn{5}{|l|}{ Almost every day (219) } \\
\hline 2007 & $\begin{array}{l}\text { Never or hardly ever } \\
(224)\end{array}$ & $\begin{array}{l}\text { Once or twice a month } \\
(228)\end{array}$ & $\begin{array}{l}\text { Once or twice a week } \\
\text { (223) }\end{array}$ & $\begin{array}{l}\text { Almost every day } \\
(220)\end{array}$ \\
\hline Never or hardly ever (224) & & & & $>$ Diff $=4 * *$ \\
\hline Once or twice a month (228) & & & $>$ Diff $=5 * *$ & $>$ Diff $=8 * * *$ \\
\hline Once or twice a week (223) & & & & $>\operatorname{Diff}=4 * * *$ \\
\hline \multicolumn{5}{|l|}{ Almost every day (220) } \\
\hline 2005 & $\begin{array}{l}\text { Never or hardly ever } \\
\text { (223) }\end{array}$ & $\begin{array}{l}\text { Once or twice a month } \\
(225)\end{array}$ & $\begin{array}{l}\text { Once or twice a week } \\
\text { (221) }\end{array}$ & $\begin{array}{l}\text { Almost every day } \\
(218)\end{array}$ \\
\hline Never or hardly ever (223) & & & & $>$ Diff $=5 * *$ \\
\hline Once or twice a month (225) & & & $>\operatorname{Diff}=4 * * *$ & $>\operatorname{Diff}=7 * * *$ \\
\hline Once or twice a week (221) & & & & $>\operatorname{Diff}=3 * * *$ \\
\hline Almost every day (218) & & & & \\
\hline
\end{tabular}

Next, over the four years in which NAEP was administrated, ELL students who practiced reading aloud almost every day had the lowest reading score compared with those who practiced reading aloud less frequently, such as, once or twice a week, once or twice a month and never or hardly ever. As shown on Table 3 above, the participants who practiced reading aloud almost every day had an average of 219 points for the 2011, 2009, 2007, and 2005 NAEP years, which was significantly lower than the average scores of those who practiced reading aloud once or twice a week (223 pts), once or twice a month (228 pts), and never or hardly ever (225 pts) in each of the corresponding years. The differences between the average score of those who practiced reading aloud almost every day and the three average scores of those who practiced reading aloud less frequently were $-4,-9$ and -6 points respectively. But it should be noticed that the partcipants who practiced reading aloud once or twice a month had highest average reading score.

Based on the same NAEP data on Table 3, Figure 1 presented a general trend of the predictive effect of reading aloud on ELL students' reading performance. Paticipants' reading scores in those four years were lowest when their teachers used reading aloud practice almost everyday. 


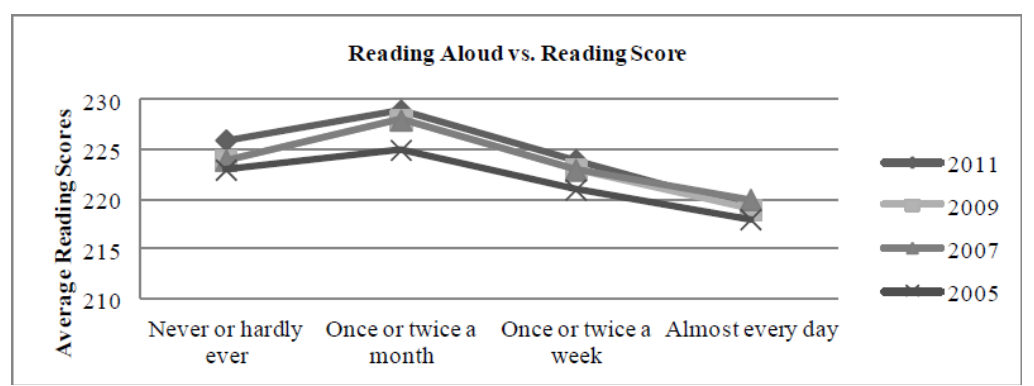

Figure 1 The trend in mean scores between variables for reading aloud instruction

My analysis of PIRLS data led to significant positive predictive effect of silent reading on ELL students' reading performance. On Table 4, the regression coefficient output, $b=28.423, t(344)=4.334, \mathrm{p}<.001$, indicated that the more frequently ELL students read silently, the higher their reading score was. Their reading score increased by 28.423 points per unit, e.g. from once to twice a week to almost every day.

TABLE 4.

SILENT READING INSTRUCTION AND ELL STUDENT READING ACHIEVEMENT IN PIRLS DATA $(N=345)$

\begin{tabular}{|c|c|c|c|c|c|}
\hline \multirow[t]{2}{*}{ Model } & \multicolumn{2}{|c|}{ Unstandardized Coefficents } & \multirow{2}{*}{$\begin{array}{l}\text { Standardized } \\
\text { Coefficients } \\
\text { Beta }\end{array}$} & \multirow[b]{2}{*}{$t$} & \multirow[b]{2}{*}{ Sig. } \\
\hline & $B$ & Std. Error & & & \\
\hline 1 (Constant) & 551.719 & 8.889 & - & 62.065 & .000 \\
\hline SCH/READ SILENTLY ALONE & 28.423 & 6.558 & .228 & 4.334 & $.000 *$ \\
\hline
\end{tabular}

Also, based on the data over the three NAEP administrations, the more frequently the participants were engaged in silent reading, the more likely they had higher reading performance. For example, the participants who read silently almost every day had the highest reading score compared with those who read silently once or twice a week, once or twice a month, and never or hardly ever. Table 5 showed that those who read silently almost every day had an average of 221 points for the 1994, 1998 and 2000 NAEP years, which was significantly higher than the average scores of those who read silently once or twice a week (215 pts), once or twice a month (191 pts) and never or hardly ever (193 pts) in these three correspondent years. The average score differences between reading silently almost every day and once or twice a week, once or twice a month and never or hardly ever were 6,30 and 28 points respectively.

TABLE 5

MEAN SCORE DIFFERENCES BETWEEN VARIABLES FOR SILENT READING INSTRUCTION IN NAEP DATA

\begin{tabular}{|c|c|c|c|c|}
\hline 2000 & $\begin{array}{l}\text { Never or hardly ever } \\
\text { (194) }\end{array}$ & $\begin{array}{l}\text { 1-2 times a month } \\
\text { (191) }\end{array}$ & $\begin{array}{l}\text { 1-2 times a week } \\
\text { (215) }\end{array}$ & $\begin{array}{l}\text { Almost every day } \\
(220)\end{array}$ \\
\hline $\begin{array}{l}\text { Never or hardly ever } \\
\text { (194) }\end{array}$ & & $<\operatorname{Diff}=5^{*}$ & $<\operatorname{Diff}=21 * * *$ & $<\operatorname{Diff}=26^{* * *}$ \\
\hline $1-2$ times a month (191) & & & $<\operatorname{Diff}=24 * * *$ & $<\operatorname{Diff}=29 * * *$ \\
\hline 1-2 times a week (215) & & & & $<$ Diff $=5^{*}$ \\
\hline \multicolumn{5}{|l|}{ Almost every day (220) } \\
\hline 1998 & $\begin{array}{l}\text { Never or hardly ever } \\
\text { (196) }\end{array}$ & $\begin{array}{l}\text { 1-2 times a month } \\
\text { (196) }\end{array}$ & $\begin{array}{l}\text { 1-2 times a week } \\
(216)\end{array}$ & $\begin{array}{l}\text { Almost every day } \\
(221)\end{array}$ \\
\hline $\begin{array}{l}\text { Never or hardly ever } \\
\text { (194) }\end{array}$ & & & $<\operatorname{Diff}=22 * * *$ & $<\operatorname{Diff}=27 * * *$ \\
\hline 1-2 times a month (191) & & & $<\operatorname{Diff}=25^{* * *}$ & $<\operatorname{Diff}=30 * * *$ \\
\hline 1-2 times a week (215) & & & & $<\operatorname{Diff}=6^{* *}$ \\
\hline Almost every day (220) & & & & \\
\hline 1994 & $\begin{array}{l}\text { Never or hardly ever } \\
\text { (190) }\end{array}$ & $\begin{array}{l}\text { 1-2 times a month } \\
\text { (191) }\end{array}$ & $\begin{array}{l}\text { 1-2 times a week } \\
(216)\end{array}$ & $\begin{array}{l}\text { Almost every day } \\
(222)\end{array}$ \\
\hline $\begin{array}{l}\text { Never or hardly ever } \\
\text { (190) }\end{array}$ & & & $<$ Diff $=26^{* * *}$ & $<$ Diff $=32 * * *$ \\
\hline 1-2 times a month (191) & & & $<\operatorname{Diff}=28 * * *$ & $<\operatorname{Diff}=31 * * *$ \\
\hline 1-2 times a week (216) & & & & $<\operatorname{Diff}=6^{* *}$ \\
\hline Almost every day (222) & & & & \\
\hline
\end{tabular}

In addition, based on the same data on Table 5, Figure 2 showed that the participant ELL students' reading scores presented an increasing trend. Those who read silently almost every day achieved the highest score. 


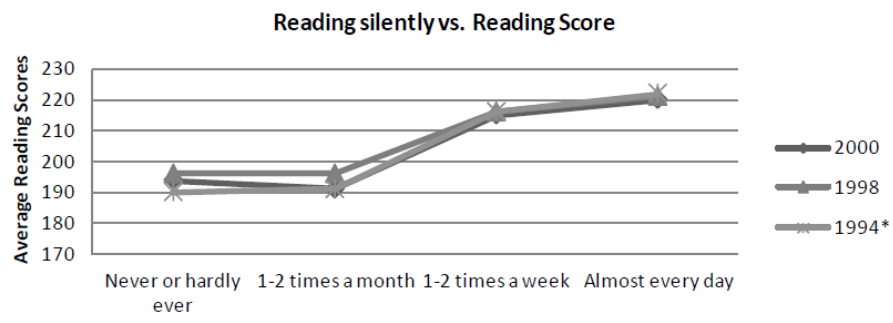

Figure 2 The trend in mean scores between variables for silent reading

In summary, the analyses of the two large scale databases in my study generally indicated that the more frequently ELL students at intermediate grade level practiced reading aloud as recommended by the policy, the poorer they tended to perform in their reading proficiency. This pattern was consistent throughout the data in several NAEP administrations. In contrast, the more frequently ELL students read silently, the higher their reading score was on both PIRLS and NAEP. Again this pattern was consistent throughout three NAEP administrations.

\section{DISCUSSION AND CONCLUSION}

The analyses of the two relevant large scale databases help develop the following understanding about the research questions in my study.

First, based on the analyses of both PIRLS and NAEP data, my study helps understand the relationship between reading aloud and ELL students' reading performance by showing consistently and repeatedly that by the fourth grade, no matter how ELL students practice reading aloud, it is no longer useful as assumed in improving their reading development. On the contrary, more frequent use of reading aloud actually hinders ELL students' reading development.

This finding is consistent with the findings of the existing studies. For example, based on 650 children's test performance and classroom observation, Meyer, Wardrop, Linn, and Hastings (1993) found that the amount of time teachers spent on reading aloud was negatively correlated with their reading achievement because the children had already developed oral fluency at earlier childhood. It suggested a developmental trajectory of oral reading fluency for ELL students, which involved the dramatic growth in the early years but a "negatively accelerating curve through the intermediate grades and perhaps into junior high school" (Fuchs, Fuchs, Hosp, and Jenkins, 2001, p. 242).

My finding challenges the rationale behind the assumption that reading aloud helps ELL students develop correspondence between the written representation and the phonological structure of words regardless of their age and first language literacy experience (Liberman, Shankweiler \& Liberman, 1989) and support that the intermediate grade level ELL students may not develop their reading comprehension by only relying on the skills of grapheme-phoneme correspondences (Torgesen \& Morgan, 1990). Thus, it may support indirectly the assumption that ELL students at fourth grade level may have stored essential linguistic knowledge in their first language environment, which may help and facilitate their English reading development (Koda, 2007).

Alternatively, it may suggest that by the fourth grade, ELL students may have had continuous exposure to oral English through their several years of schooling, which means that they have developed some "auditory experience with the target language" (Griffin, 1992, p. 784). Such experience can improve their phonological loop, a component in working memory (Hamada \& Koda, 2010). The improved phonological loop eventually helps ELL children develop "more reliable L2 phonological inventories" that facilitate their English reading comprehension (Walter, 2008, p. 455). As a result, frequent reading aloud practice is no longer useful for these ELL students.

Second, my study helps understand that by the fourth grade, silent reading can help improve the fourth grade ELL students' reading performance positively and consistently. This finding is consistent with a number of empirical studies that showed a positive relationship between silent reading and the improvement of ELL reading comprehension (Constantino, Lee, Cho \& Krashen, 1997; Kweon \& Kim, 2008; Al-Homoud \& Schmitt, 2009). What's more, it extends the existing literature that only addressed adult ESL learners who had rich first language experience and higher cognitive development.

My study further supports indirectly the theoretical assumption of the reciprocity between silent reading experience and the automaticity of basic skills. Following this assumption, silent reading helps automate ELL students' lower-order mental operations within the limited phonological awareness, which means that they do not need to process simultaneously all the amount of information and interactions in their working memory during reading (Bryant, MacLean \& Bradley, 1990; Bradley and Bryant, 1991; Stahl and Murray, 1994). Once the limited phonological awareness is automated, more attentional capacity is available. Thus, it is likely for ELL students to activate their reading experiences and skills developed in their first languages and to facilitate comprehensible input (Wallace, 1992; Krashen, 2004). When their first language reading experience and reading skills are activated, intermediate grade level ELL students are more likely to use top down approach to focus on text meaning while they pay less attention to linguistic and phonological information. In addition, through sustained silent reading, ELL students are more highly motivated to read, which creates a spiral effect of rich-get-richer (Loh, 2009). The result is the overall development of 
ELL students' reading comprehension and more competent readers who are ready for reading to learn at higher grade level (Chall, 1987).

My study and its findings offer several implications for the policy makers and practitioners in reading teaching and development for ELL learners. First, the reading development for the L1 learners, younger ELL learners, and older ELL learners may follow different patterns and the resources for their reading development can be different. Thus, it is important and necessary for policy makers as well as teachers to pay attention to these differences when making policy suggestions for reading teaching for different age groups of learners. In specific, to teach reading to older ELL learners, special attention needs be paid to their already developed first language experiences, skills, and relevant knowledge for their L2 reading development as these ELL students do not necessarily develop English reading proficiency in a similar manner as their English monolingual counterparts do. Also, teachers involved in teaching older ELL students should encourage more silent reading both at school and at home.

Because of the constraints of the data in PIRLS and NAEP, my study is unable to do in-depth analyses. However, it raises questions for future studies. These questions include 1) why reading aloud is no longer effective for intermediate grade level ELL students; 2) why occasional reading aloud has the higher effects on ELL students than either more or less frequent reading aloud practice; 3) how ELL students use their prior literacy experience and skills in silent reading; 4) whether there is difference between new immigrant ELL children and ELL children who have stayed in US for some years. To answer these questions, future studies need to rely more on qualitative methods such as interviews with ELL students and class observation.

\section{REFERENCES}

[1] Adams, M. J. (1990). Beginning to read: Thinking and learning about print. Cambridge, MA: MIT Press.

[2] Adams, M.J. (1994). Modeling the connections between word recognition and reading. In R.B. Ruddell, M.R. Ruddell, \& H. Singer (eds.), Theoretical models and processes of reading (pp. 838-863). Newark, DE: International Reading Association.

[3] Al-Homoud, F., \& Schmitt, N. (2009). Extensive reading in a challenging environment: A comparison of extensive and intensive reading approaches in Saudi Arabia. Language Teaching Research, 13(4), 383-401.

[4] Amer, A. A. (1997). The effect of the teacher's reading aloud on the reading comprehension of EFL students. ELT Journal, 51(1), 43-47.

[5] Baddeley, A., D., Gathercole, S., \& Papagno, C. (1998). The phonological loop as a language learning device. Psychological Review, 105(1), 158-173.

[6] Baer, J., Baldi, S., Ayotte, K., \& Green, P. (2007). The Reading Literacy of U.S. Fourth-Grade Students in an International Context: Results from the 2001 and 2006 Progress in International Reading Literacy Study (PIRLS) (NCES 2008-017). National Center for Education Statistics, Institute of Education Sciences, U.S. Department of Education. Washington, DC.

[7] Ball, E. W., \& Blachman, B. A. (1991). Does phoneme awareness training in kindergarten make a difference in early word recognition and developmental spelling? Reading Research Quarterly, 26(1), 49-66.

[8] Binkley, M., \& Kelly, D. (2003). A Content Comparison of the NAEP and PIRLS Fourth-Grade Reading Assessments (NCES 2003-10). U.S. Department of Education. Washington, DC: National Center for Education Statistics Working Paper.

[9] Bruck, M., Genesee, R, \& Caravolas, M. (1997). Across-linguistic study of early literacy acquisition. In B. Blachman (Ed.), Dyslexia and its treatment (pp. 45-62). Mahwah, NJ: Erlbaum.

[10] Bryant, P. E., Maclean, M., Bradley, L. \& Crossland, J. (1990). Rhyme and alliteration, phoneme detection, and learning to read. Developmental Psychology, 26(3), 429-438.

[11] Campbell, J.R., Kelly, D.L., Mullis, I.V.S., Martin, M.O., \& Sainsbury, M. (2001). Framework and specifications for PIRLS assessment 2001, Chestnut Hill, MA: PIRLS International Study Center, Lynch School of Education, Boston College.

[12] Caravolas, M., \& Bruck, M. (1993). The effect of oral and written language input on children's phonological awareness: A cross-linguistic study. Journal of Experimental Child Psychology, 55(1), 1-30.

[13] Castles, A., \& Coltheart, M. (2004). Is there a causal link from phonological awareness to success in learning to read? Cognition, 91(1), 77-111.

[14] Chall, J. S. (1987). Two vocabularies for reading. In M. G. McKeown, \& M. E. Curtis (Eds.), The nature of vocabulary acquisition (pp. 7-17). Hillsdale, NJ: Erlbaum.

[15] Chall, J, .S. (1996). Learning to read: The great debate (3rd ed.). Fort Worth, TX: Harcourt Brace.

[16] Chiappe, P., Siegel, S., \& Gottardo, A. (2002). Reading-related skills of kindergartners from diverse linguistic backgrounds. Applied Psycholinguisitcs, 23(1), 95-116.

[17] Constantino, R., Lee, S., Cho, K., \& Krashen, S. (1997). Free voluntary reading as a predictor of TOEFL scores. Applied Language Learning, 8(1), 111-18.

[18] Cummins, J. (1979): Linguistic interdependence and the educational development of bilingual children. Review of Educational Research, 49(2), 222-251.

[19] Durgunoglu, A. Y., Nagy, W. E., \& Hancin-Bhatt, B. J. (1993). Cross-language transfer of phonological awareness. Journal of Educational Psychology, 85(3), 453-465.

[20] Fuchs, L.S., Fuchs, D., Hosp, M.K., \& Jenkins, J.R. (2001). Oral reading fluency as an indicator of reading competence: A theoretical, empirical, and historical analysis. Scientific Studies of Reading, 5(3), 239-256.

[21] Gabrielatos, C. (2002). Inference procedures and implications for ELT. In R.P. Millrood (Ed.), (2002). Research methodology: Discourse in teaching a foreign language (pp. 30-52). Tambov: Tambov State University Press.

[22] Gersten, R., Baker, S. K., Shanahan, T., Linan-Thompson, S., Collins, P., Scarcella, R., \& Institute of Education Sciences (ED), W. C. (ED), Washington, DC. (2007). Effective Literacy and English Language Instruction for English Learners in the Elementary Grades. IES Practice Guide. NCEE 2007-4011. What Works Clearinghouse. 
[23] Goodman, K. S. (1976). Manifesto for a reading revolution. In F.V.Gollasch (Ed.). Language and literacy: The selected writings of Kenneth S. Goodman (pp. 231-241). London: Routledge \& Kegan Paul.

[24] Goswami, U. \& Bryant, P. (1990). Phonological skills and learning to read. London: Erlbaum.

[25] Griffin, S. M. (1992). Reading aloud: An educator comments. TESOL Quarterly, 26(4), 784-787.

[26] Hamada, M., \& Koda, K. (2010). The role of phonological decoding in second language word-meaning inference. Applied Linguistics, 31(4), 513-531.

[27] Jacobs, G. M., \& Farrell, T. (2001). Paradigm shift: Understanding and implementing change in second language education. TESL-EJ, 5(1). Retrieved from http://tesl-ej.org/ej17/a1.html (accessed 10/3/2012).

[28] Jiménez González, J. E., \& García, C. (1995). Effects of word linguistic properties on phonological awareness in Spanish children. Journal of Educational Psychology, 87(2), 193-201.

[29] Johnson, P. \& Afflerbach, P. (1985). The process of constructing main idea from text. Cognition \& Instruction 2(3/4), $207-232$.

[30] Joncas, M. (2007). PIRLS 2006 sample design. In M.O. Martin, I.V.S. Mullis \& A.M. Kennedy (Eds.), PIRLS 2006 Technical Report (pp. 35-48). Chestnut Hill, MA: TIMSS \& PIRLS International Study Center, Lynch School of Education, Boston College.

[31] Koda, K. (2005). Insights into second language reading. New York: Cambridge University Press.

[32] Koda, K. (2007). Reading and language learning: Crosslinguistic constraints on second language reading development. Language Learning, 57(1), 1-44.

[33] Krashen, S. D. 2004. The Power of Reading. Portsmouth, N.H.: Heinemann and Westport, Conn.: Libraries Unlimited.

[34] Kweon, S., \& Kim, H. (2008). Beyond raw frequency: Incidental vocabulary acquisition in extensive reading. Reading in a Foreign Language, 20(2), 191-215.

[35] Lafrance, A., \& Gottardo, A. (2005). A longitudinal study of phonological processing skills and reading in bilingual children. Applied Psycholinguistics, 26(4), 559-578.

[36] Liberman, I. Y., Shankweiler, D., \& Liberman, F. W. (1989). The alphabetic principle and learning to read. In D. Shankweiler \& I. Y. Liberman (Eds.) Phonology and reading disability: Solving the reading puzzle (pp. 1-33). International Academy of Research on Learning Disabilities Monograph Series. Ann Arbor: University of Michigan Press.

[37] Loh, J. K. K. (2009). Teacher modeling: Its impact on an extensive reading program. Reading in a foreign language, 21 (2), 93118.

[38] Meyer, L. A., Wardrop, J. L., Linn, R. L., \& Hastings, C.N. (1993). Effects of ability and setting on kindergartners' reading performance. Journal of Educational Research, 86(3), 142-160.

[39] Mullis, I.V.S., Kennedy, A.M., Martin, M.O., \& Sainsbury, M. (2006). PIRLS 2006 Assessment Framework and Specifications, 2nd Edition. Chestnut Hill, MA: Boston College.

[40] Nagy, W. E. , \& Anderson, R. C. (1999). Metalinguistic awareness and literacy acquisition in different languages. In D. Wagner, R. Venezky \& B. Street (Eds.). Literacy: An International Handbook (pp. 155-160). Boulder, CO: Westview Press.

[41] Nassaji, H., \& Geva, E. (1999). The contribution of phonological and orthographic processing skills to adult ESL reading: Evidence from native speakers of Farsi. Applied Psycholinguistics, 20(2), 241-267.

[42] National Assessment Governing Board, W. C. (2003). Background information framework for the National Assessment of Educational Progress. Retrieved from http://www.nagb.org/publications/frameworks/backinfoframenew.pdf (accessed $15 / 3 / 2012)$

[43] National Assessment Governing Board (2008). Reading framework for the 2009 National Assessment of Educational Progress. Retrieved from www.nagb.org (assessed 15/3/2012).

[44] National Center for Education Statistics. (2004). The nation's report card: Reading highlights 2003 (NCES 2004452). Washington, DC: U.S. Department of Education.

[45] Nation's Report Card. $\quad$ (2009). Retrieved from http://nationsreportcard.gov/reading_2009/nat_g4.asp?subtab_id=Tab_7\&tab_id=tab1\#tabsContainer. (assessed 15/3/2012)

[46] Nation, K., \& Cocksey, J. (2009). The relationship between knowing a word and reading it aloud in children's word reading development. Journal of Experimental Child Psychology, 103(3), 296-308.

[47] Ogle, L., Sen, A., Pahlke, E., Jocelyn, L., Kastberg, D., Roey, S., \& Williams, T. (2003). International comparisons in fourthgrade reading literacy: Findings from the Progress in International Reading Literacy Study (PIRLS) 2001 (NCES 2003- 073R). U.S. Department of Education, Institute of Education Sciences. Washington, DC: U.S. Government Printing Office.

[48] Paris, S. G., \& Hamilton, E.E. (2009). The development of children's reading comprehension. In Israel, Susan E., \& Gerald G. Duffy (eds.), Handbook of research on reading comprehension. New York: Routledge.

[49] Rutkowski, L., Gonzalez, E., Joncas, M., \& von Davier, M. (2010). International large-scale assessment data: Issues in secondary analysis and reporting. Educational Researcher, 39(2), 142-151.

[50] Stahl, S., \& Fairbanks, M. (1986). The effects of vocabulary instruction: A model-based meta-analysis. Review of Educational Research, 56(1), 72-110.

[51] Torgesen, J. K. \& Morgan, S. (1990). Phonological synthesis tasks: A developmental, functional, and componential analysis. In H.L. Swanson \& B. Keogh (Eds.), Learning disabilities: Theoretical and research issues. Hillsdale, NJ: Erlbaum.

[52] von Davier, M., Sinharay, S., Oranje, A., \& Beaton, A. (2006). The statistical procedures used in National Assessment of Educational Progress: Recent developments and future directions. In C. R. Rao \& S. Sinharay (Eds.), Handbook of statistics: Vol. 26. Psychometrics (pp. 1039-1055). Amsterdam: Elsevier.

[53] Wallace, C. (1992) Reading. Oxford: Oxford University Press.

[54] Walter, C. (2008). Phonology in second language reading: Not an optional extra. TESOL Quarterly, 42(3), 455-474.

Siping Liu was born in Wuhan, China. He received MA degree in applied linguistics from the University of Sheffield, United Kingdom in 2002 and PH.D. degree in teacher education from University of Nevada Las Vegas, United States in 2012. 
He is currently an associate professor in the College of Foreign Languages and Literature, Wuhan University, Wuhan, China. His research interests include educational linguistics, applied linguistics and American education.

Dr. Liu is a member of the American Educational Research Association, the Comparative and International Education Society and TESOL International Association. 